\title{
EPIFANIA: A LUCIDEZ PERVERSA DE CLARICE LISPECTOR
}

\author{
ABUCHAIM, Cláudia Borragini"; SIQUEIRA, João Hilton Sayeg de².
}

\section{RESUMO}

Este artigo tem por tema um estudo da concessão de epifania à personagem feminina, Ana, do conto Amor, pela autora Clarice Lispector. Por meio de uma análise interpretativista, pretendese verificar o intuito perverso da epifania, como fator presente na produção literária de Lispector que permite às suas personagens a lucidez de sua situação por meio de reflexões conscientizadoras. Para a realização desse propósito, constituem a base analítica os estudos de Vignoles (1991), Nunes (1995), Rosenbaum (1999), Sant'Anna e Colassanti (2013). Os autores afirmam que a epifania obedece a uma sequência sintagmática, que se assemelha à estrutura clássica das narrativas em início, clímax e desfecho. Manifesta-se em pré-clímax, clímax e pósclímax, que corresponde também a uma progressão da própria epifania: pré-epifania, epifania e pós-epifania. A epifania, nesse processo, funciona como um castigo perverso pela lucidez que é proporcionada.

Palavras-chave: Clarice Lispector. Epifania. Lucidez. Perversidade.

\begin{abstract}
This article has as its theme a study of the concession of epiphany to the female character, Ana, of the tale Amor, by the author Clarice Lispector. Through an interpretative analysis, the article intend to verify the perverse intention of epiphany, as a factor present in the literary production of Lispector that allows to its characters the lucidity of their situation through conscientizing reflections. For this purpose, the studies of Vignoles (1991), Nunes (1995), Rosenbaum (1999), Sant'Anna and Colassanti (2013) constitute the analytical basis. The authors state that the epiphany obeys a syntagmatic sequence, which resembles the classic narrative structure at the beginning, climax and outcome. It manifests itself in pre-climax, climax and post-climax, which also corresponds to a progression of the epiphany itself: pre-epiphany, epiphany and postepiphany. The epiphany, in this process, functions as a perverse punishment for the lucidity that is provided.
\end{abstract}

Keywords: Clarice Lispector. Epiphany. Lucidity. Wickedness.

\footnotetext{
${ }^{1}$ Doutora em Língua Portuguesa pela Pontifícia Universidade Católica de São Paulo (PUC-SP)

${ }^{2}$ Doutorado em Linguística e Letras pela Pontifícia Universidade Católica do Rio Grande do Sul. Professor titular do Programa de Estudos Pós-graduados em Língua Portuguesa da Pontifícia Universidade Católica de São Paulo (PUC-SP)
} 


\section{Um cego mascando chicles mergulhara o mundo em escura sofreguidão.}

\section{A narrativa de ficção}

A narrativa de ficção constrói um mundo múltiplo de acontecimentos e personagens, trabalha com a potencialidade, com perspectivas do real. De acordo com Perrone-Moisés (1990, p. 102): "A literatura parte de um real que pretende dizer, falha sempre ao dizê-lo, mas ao falhar diz outra coisa, desvenda um mundo mais real do que aquele que pretendia dizer".

O presente artigo, ancorado nas palavras de Perrone-Moisés, ao considerar que o texto ficcional "ao falhar" com a realidade diz muito mais do que pretendia dizer, se propôs por meio de análise interpretativista do conto Amor de Clarice Lispector a averiguar se a autora concedeu a epifania à personagem feminina com intuito perverso.

Objetivou-se apresentar uma análise do conto de Clarice Lispector que não se ateve apenas à observação da epifania, tanto estudada, quando se trata da autora. O fator de diferenciação foi perpassar a perversidade consciente de Lispector ao permitir a lucidez a sua personagem. Para a realização desse propósito, constituíram a base analítica os estudos de Vignoles (1991), Nunes (1995), Rosenbaum (1999), Sant'Anna e Colassanti (2013).

Cid Seixas assim interpreta o poder encantatório do conto:

Um conto não vale pelo que conta. Mas pelo que não conta. Pelo que se projeta no
silêncio da narrativa e fica. É precisamente aquilo que se instala, e habita para sempre
a sensibilidade e a inteligência do leitor, que é a essência do conto. E essa essência
nunca é dita, porque não cabe nos limites de umas poucas folhas de papel, embora,
paradoxalmente, caiba, comprimida? melhor: adormecida, ou encantada? nos parcos
signos poéticos contidos nessas folhas (SEIXAS, 2003, p. 21).

Umberto Eco afirmava que “[...] todo texto é uma máquina preguiçosa pedindo ao leitor que faça uma parte do seu trabalho" (ECO, 1994, p. 9).

Seja a essência do conto o silêncio, o não dito, seja uma máquina preguiçosa que precisa da ajuda do leitor para interpretá-lo, é antes de tudo o fascínio da escrita, leitura rápida e atenta que pede dedicação.

Para análise da epifania adotou-se o modelo proposto por Sant'anna e Colassanti (2013). Os autores afirmam que a epifania obedece a uma sequência sintagmática, que se assemelha com a estrutura clássica das narrativas em início, clímax e desfecho. Manifesta-se em préclímax, clímax e pós-clímax, que corresponde também a uma progressão da própria epifania: pré-epifania, epifania e pós-epifania. 
Iniciou-se a análise com uma breve reflexão do conto Amor, publicado pela primeira vez na coletânea Alguns Contos, de 1952, que apresentava os seguintes contos: Amor, Começos de uma fortuna, Mistério em São Cristóvão, O jantar, Os laços de família, Uma galinha. O livro foi publicado pelo Serviço de Documentação do Ministério da Educação e Cultura.

Amor reaparece no livro Laços de família ${ }^{3}$ (1960), que contém treze contos e apresenta como foco central o processo de aprisionamento de indivíduos em seu cotidiano doméstico. $\mathrm{O}$ livro compila os seguintes contos: Devaneio e embriaguez duma rapariga, Amor, Uma galinha, A imitação da rosa, Feliz aniversário, A menor mulher do mundo, O jantar, Preciosidade, Os laços de família, Começos de uma fortuna, Mistério em São Cristóvão, O crime do professor de matemática, $O$ búfalo.

O conto apresenta as reflexões de Ana, dona de casa, casada, da classe média urbana, que deve cuidar do marido, dos afazeres domésticos e dos filhos, sempre pronta para atender a todos. Uma típica mulher brasileira de meados do século XX, que antes de se deparar com um cego mascando chiclete, acreditava ter uma vida "perfeita".

A personagem Ana protagoniza um anonimato social de gênero. $O$ conto escrito na década de 1950 reverbera uma sociedade conduzida por teorias instauradas por homens que restringiam a liberdade e a autonomia da mulher, que configuravam uma visão androcêntrica do mundo.

Não houve emancipação da mulher na década de 1950, os moldes vigentes na sociedade eram os mesmos da década de 1940:

[...] administradora da casa, senhora prendada, responsável pela limpeza, a cozinha, as roupas, os filhos e totalmente alheia às atividades econômicas que proporcionam os rendimentos familiares. É quando as diferenças com os homens ficam ainda mais claras: o mercado de trabalho pertence a eles, tanque e fogão são 'coisas de mulher'. Dessa clareza surge a 'felicidade perfeita' do lar em que cada um cumpre a função que lhe cabe. Pois a mulher sem prendas domésticas 'é um membro inútil na sociedade conjugal' (PINSKY, 2012, p. 495).

Em 1949, Simone de Beauvoir concluiu que os principais acontecimentos da humanidade eram conduzidos pelos homens, por isso o universo feminino era isento de realizações sociais.

[...] Ora, nas religiões ocidentais, Deus Pai é um homem, um ancião dotado de um atributo especificamente viril: uma opulenta barba branca. Para os cristãos, Cristo é mais concretamente ainda um homem de carne e osso e de longa barba loura. Os anjos, segundo os teólogos não têm sexo, mas têm nomes masculinos e manifestam-se sob a

\footnotetext{
${ }^{3}$ As referências desse artigo foram retiradas do livro Laços de família, publicado inicialmente em 1960, compilado por Benjamin Moser em Todos os contos/Clarice Lispector, em 2016. A análise investigou a sociedade de 1952 , data da primeira publicação do conto Amor.
} 
forma de belos jovens. Os emissários de Deus na Terra: o papa, os bispos, de quem se beija o anel, o padre que diz a missa, o que prega, aquele perante o qual se ajoelham no segredo do confessionário são homens (BEAUVOIR, 1980, p. 31).

\title{
Os laços de família
}

O conto Amor se inicia com "a personagem numa situação corriqueira". Segundo Sant'Anna e Colassanti (2013) é o momento da pré-epifania. A vida de Ana nada tem de especial, seu cotidiano é totalmente doméstico:

\begin{abstract}
Um pouco cansada, com as compras deformando o novo saco de tricô, Ana subiu no bonde. Depositou o volume no colo e o bonde começou a andar. Recostou-se então no banco procurando conforto, num suspiro de meia satisfação. Os filhos de Ana eram bons, uma coisa verdadeira e sumarenta. Cresciam, tomavam banho, exigiam para si, malcriados, instantes cada vez mais completos (LISPECTOR, 2016, p. 145).
\end{abstract}

Escrito na década de 1950, a protagonista encarna um dia previsível na vida de uma dona de casa dessa época. Segundo Rago (2004, p. 31):

Ser mulher, até aproximadamente o final da década de 60, significava identificar-se com a maternidade e a esfera privada do lar, sonhar com um bom partido para um casamento indissolúvel e afeiçoar-se a atividades leves e delicadas, que exigissem pouco esforço físico e mental.

Ana, que em hebraico significa "pessoa benéfica, piedosa", cuidava de todos os afazeres domésticos, da casa, dos filhos, do marido. Tudo era planejado, arrumado, organizado: "Como um lavrador. Ela plantara as sementes que tinha na mão, não outras, mas essas apenas. [...] Certa hora da tarde era mais perigosa. Certa hora da tarde as árvores que plantara riam dela. Quando nada mais precisava de sua força, inquietava-se" (LISPECTOR, 2016, p. 145).

A metáfora do lavrador que planta a semente e colhe na época certa condiz com a posição de "rainha do lar" que organiza tudo no tempo certo e colhe os frutos de uma boa esposa. A protagonista assume uma identidade que, na verdade, não a identifica: dona de casa, esposa e mãe são papéis impostos pela sociedade patriarcal em que vive Ana; como numa metonímia, a parte de "ser" dona de casa tomou o lugar do seu "ser", da sua individualidade. Por isso, a hora da tarde é a "mais perigosa", a protagonista deixa de exercer um papel social e passa a ser ela mesma, esse hiato na rotina, seu momento de ociosidade a conduz à reflexão da própria vida. Esses pensamentos são perigosos porque a conduzem à solidão, a um vazio existencial .

"Força" metaforiza seu vigor físico e sua abnegação em desempenhar seu papel de mulher. Há ironia implícita em "inquietava-se", sem trabalho doméstico a executar, restava à Ana pensar, como diz o ditado popular: "mente vazia, oficina do diabo", referência cristã a pensamentos maléficos. A perversidade nasce da ociosidade: "Seja o homem responsável ou 
não pela culpa, parece que a perversidade é perceptível no jogo nascido do tédio, do tempo vazio que é preciso preencher e que preenchemos mal porque ele nos expõe à tentação" (VIGNOLES, 1991, p. 31). A tentação para Ana eram pensamentos de liberdade, de individualidade, totalmente condenados para uma mulher de meados do século XX.

Carla Bassanezi Pinsky afirma que, na década de 1950, "as mulheres eram, por natureza, destinadas ao casamento e à maternidade" (PINSKY, 2012, p. 470). A sociedade brasileira era regida pelas normas da igreja, que considerava o casamento uma missão inspirada por Deus, um ato indissolúvel e sagrado.

Para fugir da tentação Ana planejara seu futuro:

A cozinha era enfim espaçosa, o fogão enguiçado dava estouros. [...] O homem com
quem casara era um homem verdadeiro, os filhos que tivera eram filhos verdadeiros.
Sua juventude anterior parecia-lhe estranha como uma doença de vida. Dela havia aos
poucos emergido para descobrir que também sem a felicidade se vivia: abolindo-a [...]
O que sucedera a Ana antes de ter o lar estava para sempre fora de seu alcance: uma
exaltação perturbada que tantas vezes se confundira com felicidade insuportável. Sua
precaução reduzia-se em tomar cuidado na hora perigosa da tarde [...] cuidando do lar
e da família à revelia deles (LISPECTOR, 2016, p. 145-146).

“Tomar cuidado" para não pensar, Ana evitava o pensamento, mas é por meio dele que o narrador onisciente desnuda os sentimentos da personagem. A juventude anterior de Ana, supostamente a vida de mulher solteira, lhe proporcionava a liberdade, a individualidade, a felicidade, que emerge, agora, como uma doença que foi curada. A escolha pelo casamento com um "homem verdadeiro" que lhe deu "filhos verdadeiros" conduz a personagem a abolir a felicidade de sua vida; como num ato antirromântico, pois "sem a felicidade se vivia", entregase a um escapismo às avessas, foge para a realidade da vida, consola-se com o real, resigna-se com a condição de mulher. A vida era confortável e a cozinha era espaçosa, o único problema era o fogão que "enguiçado dava estouros", cuida da casa e da família "à revelia deles".

Ana aproveita o período da tarde para fazer compras, no bonde, as digressões mostram uma personagem conformada com a própria vida, que acredita ser feliz, a vida "de aceitação" que escolheu é o bastante para se sentir realizada como mulher.

O papel social de Ana é o de mulher-mãe, distanciada da exterioridade do lar, a única ambição aceitável era desenvolver uma carreira doméstica. Essa conduta da mulher

[...] implicou sua completa desvalorização profissional, política e intelectual. Esta desvalorização é imensa porque parte do pressuposto de que a mulher em si não é nada, de que deve esquecer-se deliberadamente de si mesma e realizar-se através dos êxitos dos filhos e do marido (RAGO, 1985, p. 65).

A resignação da protagonista é apenas aparente, pois em seus pensamentos reverbera uma certa náusea da vida: 
[...] De manhã acordaria aureolada pelos calmos deveres. Encontrava os móveis de novo empoeirados e sujos, como se voltassem arrependidos. Quanto a ela mesma, fazia obscuramente parte das raízes negras e suaves do mundo. E alimentava anonimamente a vida. Estava bom assim. Assim ela o quisera e escolhera. [...] Logo um vento mais úmido soprava, anunciando, mais do que o fim da tarde, o fim da hora instável. Ana respirou profundamente e uma grande aceitação deu a seu rosto um ar de mulher (LISPECTOR, 2016, p. 147).

As reflexões de Ana apresentam a tarefa doméstica repetitiva e sem objetivo final, pois a ação é terminada momentaneamente, os móveis limpos em um dia estariam novamente empoeirados pela manhã, personificados, "arrependidos” de supostamente não precisarem mais de quem os limpassem. A palavra "aureolada" apresenta ambiguidade: santifica o trabalho doméstico ou seria uma penitência de santo para quem o pratica? A vida "obscura" e "anônima" sem protagonismo, o paradoxo "raízes negras e suaves", "o fim da hora instável”, a hora em que as reflexões eram perigosas, no rosto "um ar de mulher", a resignação com a vida, mostram que não há felicidade nesse cotidiano, aparentado pela suposta escolha de vida, como se a mulher tivesse outra opção para buscar a satisfação existencial.

No bonde, Ana não tem nenhuma preocupação, até que olha para um homem parado no ponto. Nesse momento "surgem sinais de uma estranha situação, que se transforma numa epifania reveladora" (SANT’ANNA; COLASSANTI, 2013, p. 130).

\begin{abstract}
Alguma coisa intranquila estava sucedendo. Então ela viu: o cego mascava chicles... Um homem cego mascava chicles. [...] Ele mastigava goma na escuridão. Sem sofrimento, com os olhos abertos. O movimento da mastigação fazia-o parecer sorrir e de repente deixar de sorrir, sorrir e deixar de sorrir - como se ele a tivesse insultado, Ana olhava-o. E quem a visse teria a impressão de uma mulher com ódio. [...] o bonde deu uma arrancada súbita jogando-a desprevenida para trás, o pesado saco de tricô despencou-se do colo, ruiu no chão [...] Mas os ovos haviam quebrado no embrulho de jornal. [...] E como uma estranha música, o mundo recomeçava ao redor. O mal estava feito. Por quê? Teria esquecido de que havia cegos? (LISPECTOR, 2016, p. 147-148).
\end{abstract}

A visão do cego desencadeia um processo epifânico na personagem, que tenta em vão agarrar-se à realidade: “(...) ainda teve tempo de pensar por um segundo que os irmãos viriam para jantar" (LISPECTOR, 2016, p. 147).

O cego "na escuridão", "sem sofrimento", mascava chicles, o movimento da mastigação, que aos olhos de Ana, faziam-no sorrir e parar de sorrir, eram um deboche, um insulto, que desencadeia na protagonista um sentimento vergonhoso por uma pessoa com deficiência: o ódio. O desencadear de emoções é o primeiro sinal da descoberta do "eu". Os ovos quebram com a freada brusca do bonde, assim como as convicções de Ana, rompe-se a paz interior, "o mal estava feito", nos olhos "daquele que não vê", enxerga a própria infelicidade. $\mathrm{O}$ ovo metaforiza a vida da protagonista, um mundo fechado, sem possibilidades 
de inovações, de emancipação. Ao se quebrarem, libertam a realidade e as sensações, o sofrimento, os males da vida, como no mito de Pandora. A cegueira do homem despertou a visão da existência vazia, da vida perfeita, tão duramente conquistada pela protagonista. Segundo Nunes (1995), esse é momento da "tensão conflitiva", da ruptura da personagem com o mundo, a revelação de si mesmo gera uma náusea, um mal-estar perverso.

O bonde continua a andar "[...] e o cego mascando goma ficara atrás para sempre. Mas o mal estava feito" (LISPECTOR, 2016, p. 148). A autora indica na expressão "o mal estava feito" ter consciência de que a epifania concedida à protagonista era perversa, pois "o mal", aqui, seria a descoberta da própria infelicidade. "O perverso 'diverte-se' com demolir o mundo humano, como se recusasse fazer parte dele ou como se fosse impotente para nele integrar-se" (VIGNOLES, 1991, p. 67).

As digressões de Ana continuam e a epifania perversa torna-se mais latente:

A piedade a sufocava, Ana respirava pesadamente. [...] O mundo se tornara de novo
um mal-estar. Vários anos ruíam, as gemas amarelas escorriam. Expulsa de seus
próprios dias, parecia-lhe que as pessoas na rua eram periclitantes, que se mantinham
por um mínimo equilíbrio à tona da escuridão [...] O que chamava de crise viera afinal.
E sua marca era o prazer intenso com que olhava agora as coisas, sofrendo espantada.
(...) Um cego mascando chicles mergulhara o mundo em escura sofreguidão
(LISPECTOR, 2016, p. 148-149).

A protagonista em seu "mundo perfeito" era impassível, seria aqui uma ironia com os poetas parnasianos que em busca da perfeição evitavam expor o sofrimento da vida? A epifania desencadeia em Ana várias sensações: primeiro o ódio pelo cego que parecia sorrir, depois a piedade pela condição de deficiência visual, o sentimento de mal-estar que a visão do cego desencadeara impregna-se no mundo, "vários anos ruíam", todas as certezas se desvaneciam, a redoma da felicidade se quebrava, as pessoas tornavam-se "periclitantes", o choque de realidade com a vida, o sofrimento, o mundo exterior e verdadeiro penetra na alma da protagonista como um profuso acumular de sensações.

Antes de olhar para o cego, Ana não sentia nada, apenas vivia. E agora? Caíra numa extrema bondade que a fazia sofrer. Havia se protegido tanto da vida, e um "cego mascando goma" despedaçava sua existência. Costumava se observar no espelho sem se ver, o cego, representação perversa do espelho da alma, permite a Ana a lucidez de sua infelicidade. "E através da piedade aparecia a Ana uma vida cheia de náusea doce, até a boca" (LISPECTOR, 2016, p. 149). 
Desorientada, perde o ponto de descida, o turbilhão de sentimentos a enfraquece, suas "pernas débeis" não a deixam se orientar, seu coração bate de medo. Depois de andar um pouco mais, vê o portão do Jardim Botânico.

Nessa passagem pode-se cotejar, embora a autora negasse a influência do existencialismo de autores estrangeiros em sua obra, um trecho análogo ocorrido com Roquentin, o protagonista de A náusea de Jean Paul Sartre, publicado em 1938.

Ana no Jardim Botânico:

Andava pesadamente pela alameda central, entre os coqueiros. Não havia ninguém no Jardim. Depositou os embrulhos na terra, sentou-se no banco de um atalho e ali ficou muito tempo. [...] Ao seu redor havia ruídos serenos, cheiro de árvores, pequenas surpresas entre os cipós. Todo o Jardim triturado pelos instantes já mais apressados da tarde. De onde vinha o meio sonho pelo qual estava rodeada? Como por um zunido de abelhas e aves. Tudo era estranho, suave demais, grande demais. [...] Mas na aleia central estava imóvel um poderoso gato. [...] Um pardal ciscava na terra. E de repente, com mal-estar pareceu-lhe ter caído numa emboscada. Fazia-se no Jardim um trabalho secreto do qual ela começava a se aperceber. [...] Agora que o cego a guiara até ele, estremecia nos primeiros passos de um mundo faiscante, sombrio, onde vitórias-régias boiavam monstruosas. [...] Era fascinante, e ela sentia nojo (LISPECTOR, 2016, p. 150-151).

Roquentin no Jardim público:

Abandonava-me no banco, atordoado, afligido por essa profusão de seres sem origem: eclosões por todo lado, desabrochamentos; meus ouvidos zumbiam de existência, minha própria carne palpitava e se entreabria, se abandonava à germinação universal: era repugnante. 'Mas por que', pensei, 'por que tantas existências já que todas se parecem?' Para que tantas árvores, todas iguais? Tantas existências fracassadas e obstinadamente recomeçadas - como os esforços desajeitados de um inseto caído de costas? (Eu era um desses esforços). Aquela abundância não dava impressão de generosidade, ao contrário. Era melancólica, miserável, estorvada por si mesma. Aquelas árvores, aqueles grandes corpos, canhestros [...] (SARTRE, 1983, p. 136).

Os dois personagens vislumbram experiências similares sentados em um banco de jardim: a revelação plena da náusea da existência, a lucidez com que enxergam as coisas são tão devastadoras que não olham na superfície, mas no âmago dos seres que observam. Essa lucidez é perversa porque descortina o objetivo sinistro da vida, que é ir inexoravelmente ao encontro da morte: "O Jardim era tão bonito que ela teve medo do Inferno" (LISPECTOR, 2016, p. 151).

A respeito das supostas influências estrangeiras na prosa clariceana, Hélène Cixous analisa:

[...] Aí onde respiram as obras mais exigentes, ela avança. Mas, onde o filósofo perde o ânimo, ela continua, vai ainda mais longe, mais longe que qualquer tipo de saber. Por detrás da compreensão, passo a passo fundindo-se com tremor na incompreensível espessura trêmula do mundo, com o ouvido finíssimo, concentrado até para captar o ruído das estrelas, até o mínimo roçar dos átomos, até o silêncio entre dois latidos do coração. Vigia do mundo. Não sabe nada. Não leu os filósofos. E contudo juraríamos 
às vezes ouvi-los murmurar nos seus bosques. Descobre tudo (CIXOUS, 1995, p. 157158).

O fascínio e o nojo, talvez "murmurado por Sartre", se confundem diante da visão da vida e da morte que o Jardim Botânico revela à protagonista. Inebriada pelos acontecimentos, como se acordasse de um sonho, Ana se lembra dos filhos: "Mas, quando se lembrou das crianças, diante das quais se tornara culpada, ergueu-se com uma exclamação de dor" (LISPECTOR, 2016, p. 151).

Um cego que masca “chicles” a fez esquecer até os filhos. Uma possível explicação para essa cena inusitada e poderosa que desencadeia a epifania na protagonista encontra-se na crônica "Medo da eternidade", publicada duas décadas depois, em 1970, no Jornal do Brasil. O texto narra o êxtase da menina Clarice quando muito pequena em Recife ganhou uma bala especial da irmã. Não conhecia nem tinha dinheiro disponível para comprar a bala que não acabava nunca. A perplexidade diante da eternidade da bala a fez ingressar num mundo impossível, por fim, o gosto bom se perdeu e ficou apenas uma borracha cinzenta na boca que não acabava. Desesperada com a eternidade da bala, a menina Clarice simula que o chiclete caiu no chão por acidente, e o joga fora.

Gotlib (2009, p. 70) relaciona o enredo da crônica ao chicle mascado pelo cego:

Num de seus contos intitulado 'Amor' a personagem fica perplexa diante de um cego
que masca reiteradamente chicles, figuração de um outro mundo, estático e eterno,
cego que funciona como uma espécie de guia da personagem em direção ao selvagem
mundo animal e vegetal do Jardim Botânico do Rio de Janeiro, que é, ao mesmo
tempo, um mundo de delícia e de horrores. Depois de comungar em êxtase com essa
'outra realidade' iluminada e sombria, a personagem dela sai em pânico, chamando
aflita o vigia do Jardim para que lhe abra o portão de grades de ferro que já estava
fechado.

Na continuação do conto, Ana, desorientada, quase corre em direção ao portão, precisa se libertar de tanta lucidez. Encontra os portões fechados e os sacode: "O vigia apareceu espantado de não a ter visto" (LISPECTOR, 2016, p. 152). Uma breve metamorfose acontecera a Ana, a lucidez que o cego desencadeou a fez invisível aos olhos atentos do vigia do Jardim Botânico. A recordação da família e do espaço doméstico, seu habitat natural, a fez perceber a transgressão que praticara ao sentar no banco do Jardim Botânico, esquecendo-se de sua condição de mulher.

Precisava retornar ao lar, sentia-se "à beira de um desastre": "A piedade pelo cego era tão violenta como uma ânsia, mas o mundo lhe parecia seu, sujo, perecível, seu" (LISPECTOR, 2016, p. 152) A lucidez da própria existência modifica o olhar de Ana:

Abriu a porta de casa. A sala era grande, quadrada, as maçanetas brilhavam limpas, os vidros da janela brilhavam, a lâmpada brilhava — que nova terra era essa? E por 
um instante a vida sadia que levara até agora pareceu-lhe um modo moralmente louco de viver. O menino que se aproximou correndo era um ser de pernas compridas e rosto igual ao seu, que corria e a abraçava. Apertou-o com força, com espanto. Protegia-se trêmula. Porque a vida era periclitante (LISPECTOR, 2016, p. 152).

Ao entrar em casa, Ana não reconheceu mais o lar, que passou a ser uma nova terra, onde todos eram sadios em contraposição à deficiência do cego, sua vida anterior parecia "um modo moralmente louco de viver". Não reconheceu o filho, o carinho da criança ao abraçá-la causou-lhe espanto, precisava se proteger porque a vida é perigosa. A epifania que o cego desencadeara a fazia reconhecer que a vida era horrível.

Ana reflete sobre a própria lucidez: "O que faria se seguisse o chamado do cego? Iria sozinha...” (LISPECTOR, 2016, p. 152).

O pensamento de Ana, nesse momento do conto, remete às reflexões e futuras ações da personagem, mas também reverbera as inquietações das mulheres da época e da própria autora. Assim como Ana, Clarice Lispector amava ser mãe, mas não se prendeu aos "laços de família", conseguiu romper com as convenções sociais, separou-se do marido e ficou com os filhos.

No espelho das crônicas se projeta a personagem única, ou predominante, da ficção
da autora: ela própria. Romances do "eu", contos do "eu", eis o que são as suas obras:
fictício ou construído, suposto ou imaginário, "verdadeiro" ou "real", não importa, é
o "eu" da ficcionista a personagem central (heroína? anti-heroína?) de suas narrativas.
As crônicas desenham, presumivelmente, um "eu" civil, mas quando o cotejamos com
o "eu" dos romances e contos, verificamos que é o mesmo "eu". Tudo se passa como
se a escritora somente tivesse o "eu" da sua fantasia. [...] Aqui deparamos um "eu"
que, ainda quando aparentemente empírico, se patenteia imaginário, um "eu"
inventado (MOISÉS, 1989, p. 460).

A protagonista vivenciou um novo mundo: "Ela amava o mundo, amava o que fora criado - amava com nojo. [...] Tenho medo, disse. [...] Não deixe mamãe te esquecer, disselhe. [...] De que tinha vergonha? Não havia como fugir” (LISPECTOR, 2016, p. 152-153).

A vergonha incide sobre o fato de amar o mundo exterior, desbravar outros espaços, que não eram permitidos às mulheres da época do conto. O demônio da fé a atingiu e ao mesmo tempo instaurou o medo. Paradoxalmente sentiu-se forte pela lucidez e fraca por perceber que seria capaz, agora, de desistir de sua posição de mulher-mãe. Ana voltou para casa, refugiou-se em seu cotidiano para livrar-se deste sentimento de amor e náusea. Acreditou não ter outra opção: "Não havia como fugir.", escolheu a família por estar presa em seus laços de convenção social. Segundo Nunes (1995) é um momento de "tensão conflitiva", o personagem estabelece uma ruptura com o mundo.

A beleza e o fascínio da vida/morte do Jardim Botânico e o amor pelo cego perseguiam o pensamento de Ana. Tinha piedade com a nova lucidez, mas era "piedade de leão". 
A percepção da protagonista passou a ser minimalista. Sua vida anterior é ressignificada, mesmo em seu cotidiano doméstico percebia a força da natureza.

\begin{abstract}
Mas a vida arrepiava-a, como um frio. Ouvia o sino da escola, longe e constante. O pequeno horror da poeira ligando em fios a parte inferior do fogão, onde descobriu a pequena aranha. Carregando a jarra para mudar a água - havia o horror da flor se entregando lânguida e asquerosa às suas mãos. [...] Perto da lata de lixo, esmagou com o pé a formiga. O pequeno assassinato da formiga. O mínimo corpo tremia. [...] Os besouros de verão. O horror dos besouros inexpressivos. Ao redor havia uma vida silenciosa, lenta, insistente. Horror, horror (LISPECTOR, 2016, p. 153 - 154).
\end{abstract}

$\mathrm{Na}$ descrição das coisas e dos bichos que habitavam a casa descortinava-se o horror: poeira, aranha, formiga, besouros e insetos. A personificação da flor, que simbolizava o amor, ligada paradoxalmente aos adjetivos "lânguida" e "asquerosa", mostra como o encontro com o cego suscitou em Ana a náusea pela vida. A epifania concedida pela autora é perversa porque desperta na protagonista a consciência de sua infelicidade. "Uma noite em que a piedade era tão crua como o amor ruim. Entre os dois seios escorria o suor. A fé a quebrantava, o calor do forno ardia nos seus olhos" (LISPECTOR, 2016, p. 154).

A família reúne-se para jantar: o marido, os filhos, os irmãos e suas mulheres, os filhos dos irmãos. Ana tenta voltar à normalidade e pensar em coisas triviais:

\footnotetext{
Apesar de ter usado poucos ovos, o jantar estava bom. [...] Eles rodeavam a mesa, a família. Cansados do dia, felizes em não discordar, tão dispostos a não ver defeitos. Riam-se de tudo, com o coração bom e humano. As crianças cresciam admiravelmente em torno deles. E como a uma borboleta, Ana prendeu o instante entre os dedos antes que ele nunca mais fosse seu (LISPECTOR, 2016, p. 154).
}

A cena descrita assemelha-se à rotina alienante e perfeita do quadrinho: "Lar doce lar", tão utilizado pelas famílias patriarcais. O lar deveria ser doce, sem conflitos, perfeito. Rir de tudo reverbera a bondade e a humanidade familiar, o tempo é marcado pelo crescimento das crianças. Ana tenta fazer o impossível: "prender o instante entre os dedos”, tenta em vão reaver "o coração bom e humano". Mas assim como os ovos, algo havia se quebrado, transformandose em seu interior. A metamorfose completou-se: “[...] ela era uma mulher bruta que olhava pela janela" (LISPECTOR, 2016, p. 154).

A epifania desencadeada pelo cego transtornou a vida da protagonista, que olhava pela janela e tentava ordenar os acontecimentos do dia:

O que o cego desencadeara caberia nos seus dias? Quantos anos levaria até envelhecer de novo? Qualquer movimento seu e pisaria numa das crianças. Mas com uma maldade de amante, parecia aceitar que da flor saísse o mosquito, que as vitóriasrégias boiassem no escuro do lago. O cego pendia entre os frutos do Jardim Botânico (LISPECTOR, 2016, p. 155).

O pensamento introspectivo apresenta uma crise existencial, Lispector arremessa o leitor num labirinto de incertezas, numa intimidade sádica transpõe o limite da ficção. As 
interrogações presentes nesse trecho desnudam as incertezas, a vulnerabilidade da personagem. A lucidez proporcionada pelo cego instigou a "maldade de amante" que pisaria "numa das crianças". Há um certo erotismo e satanismo nessa expressão, Ana aceita a vida real, a maldade e a beleza do Jardim Botânico, o ciclo cruel e fascinante da vida. Em pensamento, é conduzida novamente para o momento da epifania, mas a crise é tão intensa que numa imagem surreal o cego torna-se mais um fruto do Jardim Botânico.

De repente Ana ouviu um grande estouro do fogão e com medo correu para a cozinha, voltou ao mundo real. Assim como o tranco do bonde quebrou os ovos e as convicções da protagonista, o estouro do fogão quebrou a epifania e o enredo introspectivo. Iniciou-se um discurso direto entre a protagonista e o marido:

- O que foi?! gritou vibrando toda.

Ele se assustou com o medo da mulher. E de repente riu entendendo:

- Não foi nada, disse, sou um desajeitado. Ele parecia cansado, com olheiras.

Mas diante do estranho rosto de Ana, espiou-a com maior atenção. Depois atraiu-a a si, em rápido afago.

- Não quero que lhe aconteça nada, nunca! disse ela.

- Deixe que pelo menos me aconteça o fogão dar um estouro, respondeu ele sorrindo (LISPECTOR, 2016, p. 155).

A reação emocional de Ana assustou o marido, que pareceu "cansado com olheiras". Geralmente não observava a esposa, chegava sempre cansado do trabalho. Tudo estava sempre perfeito e não havia motivo para preocupações. Mas percebeu que alguma coisa havia acontecido, "diante do estranho rosto" da mulher. A preocupação da esposa não era natural, assim como não era natural o que se seguiu:

Num gesto que não era seu, mas que pareceu natural, segurou a mão da mulher, levando-a consigo sem olhar para trás, afastando-a do perigo de viver. Acabara-se a vertigem de bondade. E, se atravessara o amor e o seu inferno, penteava-se agora diante do espelho, por um instante sem nenhum mundo no coração. Antes de se deitar, como se apagasse uma vela, soprou a pequena flama do dia (LISPECTOR, 2016, p. $155)$.

O marido conduziu Ana com carinho para o quarto, "num gesto que não era seu". A passagem evidencia que o casal não tinha hábitos amorosos; em nenhum momento de sua introspecção a protagonista expressou "amor" pela família. A epifania desencadeou o amor pelo cego e pela vida. O título marca-se pela ironia, a escolha de Ana pela família foi impulsionada pela sociedade patriarcal da época que não permitia à mulher a independência, a individualidade.

O término do conto leva ao questionamento que Ana fizera antes de o marido derramar o café no fogão: “O que o cego desencadeara caberia nos seus dias?” O marido a afasta "do perigo de viver" que metaforiza a felicidade, e a conduz de volta para a rotina familiar de dona 
de casa, esposa e mãe que sempre tivera. Evidencia-se a pós-epifania: “esgota-se a epifania e a personagem volta ao cotidiano modificada" (SANT'ANNA; COLASSANTI, 2013, p. 130).

Naquele dia, no Jardim Botânico vivenciara "o amor e o inferno", reconhecia que a vida pulsava em suas veias e era possível expressar sentimentos e pensamentos, agora, penteava-se diante do espelho "sem nenhum mundo no coração", voltava a seu anonimato cotidiano. Era preciso apagar "a pequena flama do dia", qual teria sido a intensidade dessa flama? Como seria o amanhecer? Agora que vivenciara novamente a felicidade, seria possível voltar à monotonia da vida cotidiana e ainda acreditar que "sem a felicidade se vivia"?

\section{A epifania perversa}

Os textos de Clarice Lispector compartilham com o leitor, por meio dos pensamentos e divagações das personagens, seus segredos mais inquietantes. Clarice induz a personagem a beber a amargura de sua existência, sem o livre arbítrio para se desvencilhar da dor vivente, carrega apenas a lucidez do próprio fracasso, nesse sentido a epifania é perversa também por projetar a angústia da personagem no próprio leitor.

Patrick Vignoles assim revela a intenção perversa do texto:

[...] a perversão-objeto da narrativa passa a engendrar a função perversa do próprio texto, visto que ele foi escrito ou reproduzido para ser lido, isto é, imaginado, representado para uma consciência a quem o espetáculo da falta fascina (VIGNOLES, 1991, p. 104).

Yudith Rosenbaum confirma a perversidade nos textos de Lispector:

[...] envolve o leitor, qual marinheiro encantado pela sereia, para em seguida demolir suas convicções e afogá-lo nas águas de uma escrita letal. E é o 'de-dentro' mesmo desse leitor que se vê invadido, quase despercebidamente, pelas teias dessa aranha tecelã (ROSENBAUM, 1999, p. 134).

Lispector, no conto analisado, apresentou um cego que "mascava chicles", nada mais prosaico! Nos olhos "daquele que não vê", a protagonista Ana teve a visão da própria infelicidade. A epifania, nessa perspectiva, funcionou como um castigo perverso sendo que a mesma, após a lucidez da própria vida, se encontrou em um "inferno humano", do qual não poderia se livrar.

\section{Referências}

BEAUVOIR, Simone de. O segundo sexo/Simone de Beauvoir. Rio de Janeiro: Nova Fronteira, 1980. 
CIXOUS, Hélène. La risa de la medusa. Ensayos sobre la escritura. Barcelona:

Madrid/San Juan, Anthropos/ Dirección General de la Mujer/ Universidad de Puerto Rico, 1995.

ECO, Umberto. Seis passeios pelos bosques da ficção. São Paulo: Companhia das Letras, 1994.

GOTLIB, Nádia Battella. Clarice: Uma vida que se conta. 6 ed. rev. e aum. - São Paulo: Editora da Universidade de São Paulo, 2009.

LISPECTOR, Clarice. Todos os contos/Clarice Lispector. Organização de Benjamin Moser. Rio de Janeiro: Rocco, 2016.

MOISÉS, Massaud. História da Literatura Brasileira: Modernismo. São Paulo: Cultrix, 1989.

NUNES, Benedito. Leitura de Clarice Lispector. São Paulo, Quiron, 1995.

PERRONE-MOISÉS, Leyla. Flores da escrivaninha. São Paulo, Companhia das Letras, 1990.

PINSKY, Carla Bassanezi. A era dos modelos rígidos. In: PINSKY, Carla B.; PEDRO, Joana M. (org.). Nova História das mulheres no Brasil. São Paulo: Contexto, 2012, p. 469 512.

RAGO, Margareth. Do Cabaré ao Lar: a utopia da cidade disciplinar. Rio de Janeiro: Paz e Terra, 1985.

Ser mulher no século XXI ou carta de alforria. In: VENTURI, G; RECAMÁN, M; OLIVEIRA, S. (orgs.). A mulher brasileira nos espaços públicos e privados. São Paulo: Ed. Fundação Perseu Abramo, 2004.

ROSENBAUM, Yudith. Metamorfoses do mal. Uma leitura de Clarice Lispector. São Paulo: Editora da Universidade de São Paulo: Fapesp, 1999.

SANT'ANNA, Affonso Romano de; COLASSANTI, Marina. Com Clarice. São Paulo: Editora Unesp, 2013.

SARTRE, Jean Paul. A náusea. Trad. de Rita Braga. Rio de Janeiro: Nova Fronteira, 1983. SEIXAS, Cid. Os riscos da cabra cega? Recortes de crítica ligeira. Feira de Santana: UEFS Editora, 2003.

VIGNOLES, Patrick. A Perversidade: ensaio e textos. Tradução: Nícia Adan Bonatti. Campinas, SP: Papirus, 1991. 